\title{
Demagnetisasi Arus Inrush pada Transformator Satu Fasa 1 kVA Menggunakan Metode Pengurangan Sisa Medan Magnet dengan Menggunakan Sumber Tenaga Berfrekuensi Sangat Rendah
}

\author{
Dicky Wahyu Darmawan, I Made Yulistya Negara, dan Dedet Candra Riawan \\ Jurusan Teknik Elektro, Fakultas Teknologi Industri, Institut Teknologi Sepuluh Nopember (ITS) \\ Jl. Arief Rahman Hakim, Surabaya 60111 \\ E-mail: dicky.wahyu.1994@gmail.com,yulistya@ee.its.ac.id, dedet@ee.its.ac.id
}

\begin{abstract}
Abstrak - Pada penelitian ini akan membahas tentang pembuatan sebuah alat yang dirancang untuk menghilangkan fluks sisa pada inti transformator satu fasa $1 \mathrm{kVA}$. Tujuan utama dari menghilangkan fluks sisa pada transformator yaitu untuk mengurangi lonjakan arus inrush ketika transformator dienergisasi, dan meningkatkan keandalan dari transformator tersebut, hal ini lebih dimaksudkan untuk mengurangi rugi rugi yang terjadi akibat adanya fluks sisa.

Saat ini ada banyak metode yang digunakan untuk mereduksi besarnya arus inrush. Diantaranya adalah menggunakan metode shunt kapasitor, variable frequency - constant voltage (VFCV), dan variable voltage - constant frequency (VVCF). Menggunakan metode variable frequency - constant voltage, alat demagnetisasi yang dibuat pada penelitian ini merupakan sebuah rangkaian saklar semikonduktor yang dirangkai dengan input sumber tegangan DC dan output yang dihubungkan dengan belitan primer tranformator. Alat ini berkerja dengan cara membolakbalik polaritas sumber tegangan DC sesuai pengaturan waktu yang telah ditentukan, sehingga frekuensinya berubah dari frekuensi rendah menjadi frekuensi tinggi.

Setelah dilakukan proses demagnetisasi menggunakan alat demagnetisasi tersebut, besarnya nilai arus inrush bisa berkurang hingga lebih dari $50 \%$. Sebagai perbandingan, proses demagnetisasi yang dilakukan menggunakan alat dengan metode yang lain, yaitu VVCF, hanya mampu mengurangi arus inrush sebesar $37,3 \%$. Selain itu, waktu yang dibutuhkan untuk melakukan proses demagnetisasi menggunakan metode VFCV hanya 1,46 detik saja atau 1 detik lebih cepat daripada metode VVCF.
\end{abstract}

Kata Kunci-Transformator satu fasa, alat demagnetisasi, variable frequency - constant voltage.

\section{PENDAhUluan}

$\mathrm{T}$ RANSFORMATOR merupakan peralatan induksi elektromagnetik yang paling banyak digunakan pada sistem kelistrikan. Hal ini disebabkan oleh jaringan transmisi dan distribusi jarak jauh yang diterapkan di Indonesia. Jarak antara pembangkit listrik dan beban terletak sangat jauh sehingga membutuhkan transformator daya untuk menaikkan dan menurunkan tegangan agar rugi - rugi yang dihasilkan selama proses penyaluran tenaga listrik dapat diminimalisir. Salah satu fenomena transformator yang tidak diinginkan adalah arus inrush. Ketika transformator dihubungkan dengan tegangan arus bolak balik maka akan ada arus yang besarnya melebihi arus nominal yang melewati belitan transformator tersebut, itulah yang dinamakan arus inrush. Besarnya bisa 8 hingga 10 kali arus beban penuh tergantung dari besarnya fluks sisa pada inti transformator dan impedansi rangkaian. Dampak negatif yang dihasilkan oleh arus inrush diantaranya:

1. Memungkinkan terjadinya kesalahan operasi pada sistem pengaman beban lebih dan gangguan internal yang menyebabkan lepasnya transformator dari sistem.

2. Dapat merusak transformator karena kerusakan mekanik pada belitan yang teraliri arus inrush.

3. Timbulnya masalah kualitas daya pada sistem kelistrikan (overvoltages dan voltage sags)

Hal itu tentunya dapat merugikan industri - industri yang menggunakan transformator sebagai salah satu komponen pada sistem kelistrikannya. Oleh karena itu, diperlukan adanya sebuah alat yang dapat mengurangi arus inrush untuk menghindari dampak negatif yang telah disebutkan diatas dan menambah lifetime dari transformator tersebut.

Beberapa metode yang dapat digunakan untuk mengurangi arus inrush transformator antara lain, sequential phase energization, menggunakan kapasitor, pre-insertion resistor, auxiliary load; metode pengurangan fluks sisa [1], [2] dan metode pengontrolan waktu peralihan (switching time) [3], [4]. Tiap - tiap metode itu memiliki kelebihan dan kekurangannya masing - masing. Saat ini sudah ditemukan metode paling efektif untuk mengurangi arus inrush, yaitu dengan mendemagnetisasi inti transformator.

Dalam Tugas Akhir ini, "Demagnetisasi Arus Inrush pada Transformator Satu Fasa 1 kVA Menggunakan Metode Pengurangan Sisa Medan Magnet dengan Sumber Tenaga Berfrekuensi Sangat Rendah", akan dikembangkan metode Variable Frequency - Constant Voltage (VFCV) untuk mendemagnetisasi inti besi pada sebuah transformator satu fasa $1 \mathrm{kVA}$. Metode ini nantinya dikembangkan sedemikian rupa dan diharapkan dapat diaplikasikan menjadi sebuah alat yang memanfaatkan sebuah sumber DC dan dirangkai dengan rangkaian inverter DC ke AC agar menghasilkan arus bolak balik yang nantinya diinjeksikan ke inti transformator dalam rentang waktu tertentu sebelum dihubungkan dengan sumber tegangan 220 Volt (energisasi). Kelebihan dari metode VFCV ini adalah proses demagnetisasi yang singkat sehingga dapat mempercepat proses energisasi transformator tersebut. 


\section{TINJAUAN PUSTAKA}

\section{A. Arus Inrush Transformator}

Saat transformator pertama kali dihubungkan ke sumber tegangan bolak - balik, maka akan muncul aliran arus magnetisasi yang mengalir melalui kumparan primer dari transformator. Arus tersebut digunakan untuk proses energisasi yaitu agar muncul fluks pada inti ferromagnetik. Arus magnetik pada awal proses energisasi biasanya memiliki nilai hingga 8 hingga 12 kali lebih besar dari arus beban penuh transformator. Arus itulah yang dinamakan arus inrush dan merupakan salah satu fenomena transien yang dapat terjadi pada sistem kelistrikan. Besarnya nilai arus inrush tergantung dari magnitudo tegangan sumber, fluks sisa di dalam inti transformator, dan impedansi total dari rangkaian saat dihubungkan dengan sumber tegangan listrik. Arus ini diperlukan sampai nilai maksimum fluks mencapai kondisi tunak dan inti menjadi jenuh [5], [6]. Arus inrush terdiri dari 2 bagian antara lain arus magnetisasi, yakni arus yang diperlukan untuk menghasilkan fluks pada inti transformator, dan arus rugi inti, yakni arus yang diperlukan untuk rugi histerisis dan rugi arus eddy terjadi.

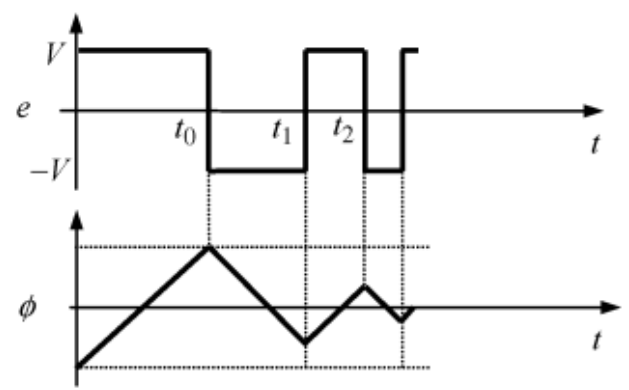

Gambar 1 Pengaruh fluks sisa terhadap arus inrush [1]

Arus inrush terjadi di dalam transformator ketika fluks sisa tidak memenuhi nilai sesaat fluks dalam kondisi tunak. Laju perubahan fluks sesaat di dalam transformator sebanding dengan jatuh tegangan sesaat pada lilitan yang terhubung sumber. Selama transformator beroperasi secara kontinyu, kondisi fluks puncak berada di nilai negatif saat tegangan berada pada titik nol. Namun, selama proses energisasi, fluks pada inti transformator harus bermula pada titik nol. Sehingga untuk menaikkan tegangan dari nol fluks magnet akan mencapai nilai puncak berkali lipat dibandingkan dengan kondisi normal. Akibat ketidaklinieran karakteristik kurva magnetisasi, pada kondisi saturasi jumlah gaya gerak magnet yang tidak sebanding dibutuhkan untuk membangkitkan fluks magnet. Sehingga arus kumparan yang dibutuhkan untuk membuat gaya gerak magnet agar dapat menimbulkan fluks pada inti transformator akan meningkat dibandingkan pada kondisi normal.

Gambar 1 menunjukkan pengaruh fluks sisa terhadap besarnya nilai arus inrush yang mengalir pada kumparan primer transformator saat pertama kali dienergisasi dengan sumber tegangan bolak - balik. Dapat dilihat, saat tidak ada fluks sisa pada inti transformator, arus inrush hanya sebesar 200 Ampere. Sedangkan saat ada fluks sisa, terjadi lonjakan arus hingga mencapai 3 kali lipat. Tentu hal tersebut bisa sangat merugikan karena dapat menyebabkan kegagalan koordinasi sistem proteksi arus lebih dan merusak belitan transformator apabila keadaan tersebut terjadi terus menerus.

\section{B. Metode Variable Frequency - Constant Voltage (VFCV)}

Ada banyak cara untuk mengurangi besarnya arus inrush dan mendemagnetisasi fluks sisa pada inti transformator. Salah satu cara yang paling mudah adalah menggunakan metode VFCV atau Variable Frequency - Constant Voltage, gambar 2. Metode ini memanfaatkan sumber tegangan DC yang diubah menjadi keluaran tegangan AC berbentuk kotak. Frekuensi yang digunakan berubah tiap setengah periode dengan frekuensi awalan yang sangat rendah. Seiring berjalannya waktu, frekuensi tadi akan bertambah cepat di setiap periode setengah gelombang.

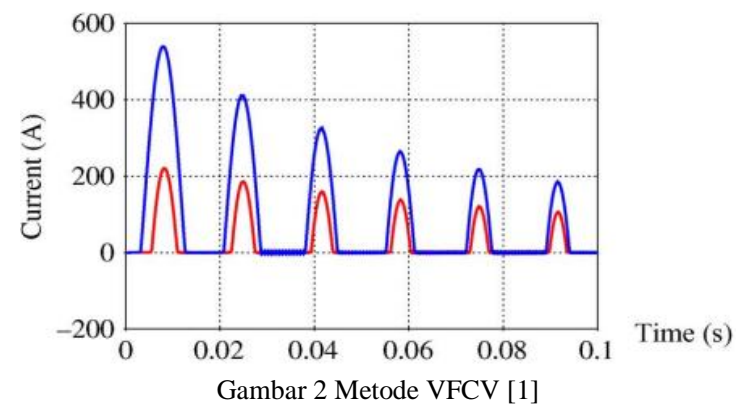

Prinsip pengurangan fluks sisa menggunakan metode demagnetisasi ini didapatkan dari hukum Faraday yaitu ketika sebuah sumber searah dihubungkan ke induktor, maka arus pada induktor tersebut akan naik secara linier terhadap waktu sesuai dengan besarnya tegangan input dari sumber tadi. Kenaikan arus secara linier terhadap waktu dapat ditulis dengan persamaan berikut,

$$
i(t)=\int v(t) . d t=\frac{V}{L} t
$$

Proses demagnetisasi dimulai ketika $t=t_{0}$, Saat arus sudah mencapai nilai maksimum $\mathrm{I}_{\max }$, maka polaritas tegangan yang tadinya positif diubah ke polaritas negatif. Kemudian arus yang tadinya sudah berada pada puncak polaritas positif akan menurun secara linear hingga mencapai titik saturasi negatif pada waktu $t=3 t_{0}$. Pada titik itu, terbentuk sebuah gelombang kotak dengan frekuensi sebesar $1 / \mathrm{T}$ dimana $\mathrm{T}$ merupakan periode gelombang antara 0 hingga ke $3 t_{0}$. Gelombang fluks yang terbentuk pada proses demagnetisasi juga berbentuk seperti gelombang arus, gambar 3. Bentuk gelombang fluks yang sama dengan gelombang arus terjadi karena fluks berbanding lurus dengan arus magnetisasi sehingga terjadi kenaikan maupun penurunan fluks secara linier terhadap tegangan masukan atau input. Hal tersebut didasarkan pada persamaan berikut,

$$
\varnothing=L i
$$

persamaan 2 menunjukkan bahwa fluks $(\varnothing)$ berbanding lurus terhadap kenaikan maupun penurunan arus (i) karena nilai induktor $L$ tidak akan berubah sebab induktansi berhubungan dengan jumlah belitan dan jenis kawat belitannya. 


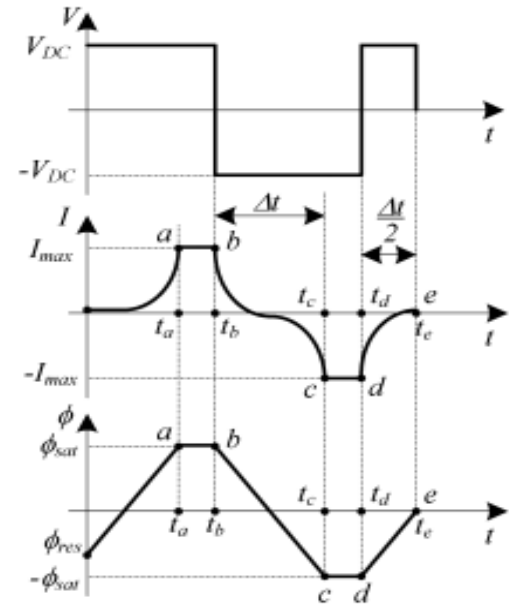

Gambar 3 Hubungan tegangan, arus, dan fluks [1]

\section{PeRAnCANGAn Alat Demagnetisasi}

\section{A. Perancangan Alat Demagnetisasi}

Proses demagnetisasi arus inrush merupakan hal yang sangat krusial pada penelitian tugas akhir kali ini. Lonjakan arus yang sangat tinggi di awal proses energisasi transformator memang dapat berdampak buruk bagi sistem proteksi maupun terhadap lifetime transformator itu sendiri. Seperti yang dibahas pada bab sebelumnya, saat transformator pertama kali dihubungkan ke sumber tegangan bolak - balik, maka akan muncul aliran arus magnetisasi yang mengalir melalui kumparan primer dari transformator. Arus tersebut digunakan untuk proses energisasi yaitu agar muncul fluks pada inti ferromagnetik. Arus magnetik pada awal proses energisasi biasanya memiliki nilai hingga 8 hingga 12 kali lebih besar dari arus beban penuh transformator [7]. Oleh karena itu, diperlukan adanya sebuah alat yang dapat mengurangi besarnya arus inrush. Alat demagnetisasi ini dirancang sedemikian rupa agar mudah saat digunakan dan mampu mengurangi besarnya nilai puncak arus inrush pada ketika dilakukan proses energisasi.

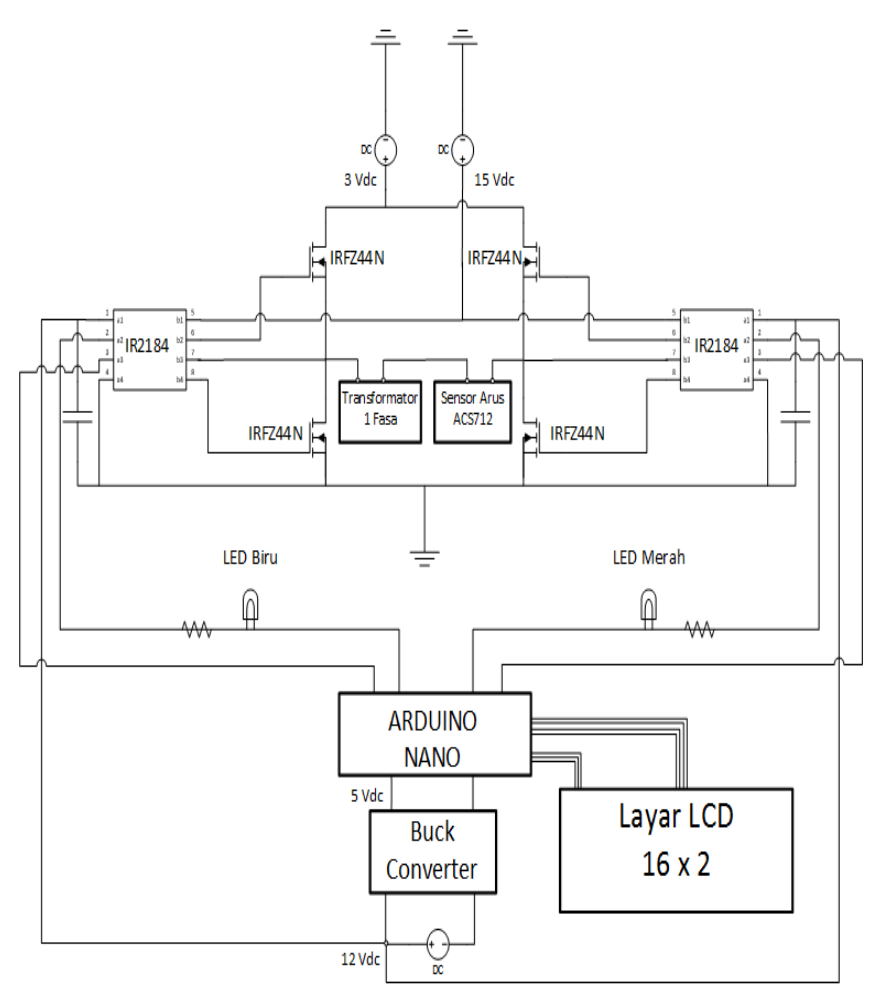

Gambar 4 Rancangan alat demagnetisasi

Sebuah demagnetizer yang dibuat ini bekerja berdasarkan prinsip kerja rangkaian fullbridge inverter yang menggunakan 4 buah MOSFET sebagai saklar semikonduktornya. Alat demagnetisasi ini akan mendapatkan input atau masukan sumber tegangan dan arus searah yang nantinya diubah menjadi gelombang bolak balik berbentuk kotak. Jika dilihat pada gambar 3 pada bab 2, sumber tegangan DC yang diinjeksi ke inti transformator mengakibatkan kenaikan arus secara linier. Alat demagnetisasi yang digunakan untuk mengurangi fluks sisa pada inti transformator merupakan sebuah rangkaian fullbridge inverter yang menggunakan suplai tegangan DC dan menghasilkan gelombang AC berbentuk kotak. Skema rangkaian yang digunakan sama dengan gambar 4 dimana terdapat 3 bagian utama yaitu MOSFET dan gate drivernya, sensor arus, serta sebuah kontroler.

Pencarian nilai arus mencapai kondisi saturasi dilakukan pada saat melakukan uji hubung terbuka yang sudah dijelaskan pada subbab sebelumnya. Dari hasil pengujian tersebut ditetapkan arus magnetisasi (Im) mengalami kondisi saturasi saat bernilai 1,16 ampere. Saat itu arus eksitasi DC (Ip) berada pada nilai 1,2 ampere. Modul ACS hanya dapat mengukur besarnya arus eksitasi yang masuk ke sisi primer transformator, sehingga pembacaan arus saturasi pada modul ACS ditetapkan sebesar 1,2 ampere agar kemudian diteruskan menuju modul mikrokontroller sebagai sinyal untuk melakukan proses pensaklaran. Persamaan yang digunakan untuk menentukan pembacaan arus saturasi yang dilakukan oleh sensor arus ACS 712 adalah,

$$
V_{\text {analog }}=\left(I_{\text {sat }} x \text { Sensitivity }\right)+V_{\text {offset }}
$$


dimana:

$V_{\text {analog }}=$ tegangan analog dari pembacaan ACS $(\mathrm{mV})$

$I_{\text {sat }}=$ arus saturasi yang ditetapkan (A)

Sensitivity $=$ sensitivitas ACS712 $(\mathrm{mV} / \mathrm{A})$

$V_{\text {offset }}=$ tegangan offset dari hasil kalibrasi 0 ampere $(\mathrm{mV})$

Setelah mendapatkan tegangan analog dari pembacaan sensor arus, langkah selanjutnya adalah mengubah tegangan analog tadi menjadi bentuk digital melalui persamaan berikut ini,

$$
V_{\text {digital }}=\frac{\text { Vanalog }}{5000} 1024
$$

Dengan ketentuan:

$V_{\text {digital }}=$ tegangan digital konversi tegangan analog $(\mathrm{mV})$

$5000=$ Vcc 5 volt pada mikrokontroller $(\mathrm{mV})$

$1024=$ jumlah bit maksimal pada mikrokontroller

Dari persamaan 4 dan 3.2 akan didapatkan arus saturasi positif yang dibaca oleh mikrokontroller:

$$
\begin{aligned}
& V_{\text {analog }}=(1,2 \times 100)+2509=2629 \mathrm{mV} \\
& V_{\text {digital }}=\frac{2629}{5000} 1024=538 \mathrm{mV}
\end{aligned}
$$

Dari persamaan yang sama juga akan didapatkan arus saturasi negatif yang dibaca oleh mikrokontroller:

$$
\begin{aligned}
& V_{\text {analog }}=2509-(1,2 \times 100)=2389 \mathrm{mV} \\
& V_{\text {digital }}=\frac{2389}{5000} 1024=489 \mathrm{mV}
\end{aligned}
$$

Hasil konversi arus analog menjadi tegangan digital ini dimasukkan ke dalam program mikrokontroller sebagai tolak ukur kondisi saturasi pada arus magnetisasi agar mikrokontroller melakukan proses pensaklaran dan merubah polaritas tegangan output positif menjadi negatif serta sebaliknya.

Alat demagnetisasi arus inrush pada transformator satu fasa ini menggunakan 3 buah sumber DC. Sumber DC yang pertama digunakan untuk mensuplai gate driver IR2184 yang membutuhkan tegangan antara $10 \mathrm{Vdc}$ hingga $20 \mathrm{Vdc}$. Pada prakteknya, sumber tegangan DC yang digunakan untuk mensuplai IR2184 sebesar 12 Vdc. Selain itu, tegangan 12 $\mathrm{Vdc}$ ini juga digunakan sebagai suplai yang langsung terhubung dengan buck converter yang langsung menurunkan tegangan tersebut menjadi $5 \mathrm{Vdc}$ untuk kemudian di salurkan ke mikrokontroller.

Sumber tegangan DC yang kedua memiliki 2 panel dimana panel bagian kanan digunakan sebagai suplai utama rangkaian demagnetisasi yaitu sebesar $3 \mathrm{Vdc}$ dan panel sebelah kiri digunakan untuk mensuplai pin $\mathrm{V}_{\mathrm{B}}$ pada IR2184 dengan nilai 15 Vdc. Kedua panel tersebut, yaitu antara panel kiri dan panel kanan bekerja secara independen sehingga tidak saling terhubung satu sama lain. Untuk suplai arus searah pada sumber DC tersebut menyesuaikan dengan besar tegangan yang digunakan. Sesuai dengan hasil pengujian dan pengukuran, besarnya resistansi pada transformator adalah sekitar $2 \Omega$. Sehingga apabila kita menggunakan $3 \mathrm{Vdc}$ sebagai tegangan utama yang mensuplai transformator, maka arus yang diinjeksikan besarnya sekitar 1.2 Ampere. Sedangkan untuk suplai DC menuju pin $\mathrm{V}_{\mathrm{B}}$ dan IR2184 tidak memerlukan suplai arus yang besar karena resistansi komponen tersebut nilainya sangat besar.

Nilai $15 \mathrm{Vdc}$ merupakan hasil dari $\mathrm{V}_{\mathrm{S}}+12 \mathrm{Vdc}$ yang mana rumus tersebut menyesuaikan dengan parameter yang ada pada datasheet komponen. Suplai utama sebesar $3 \mathrm{Vdc}$ didapatkan sesuai dengan persamaan berikut,

$$
V_{d c}=(I x R)+\left(2 x r_{d} x I\right)
$$

Berdasarkan pengujian, didapatkan resistansi pada transformator sebesar $1,95 \Omega, \mathrm{r}_{\mathrm{d}}$ pada MOSFET 17,5 $\mathrm{m} \Omega$ dan arus saturasi sebesar 1,2 A. Sehingga didapatkan tegangan suplai maksimal adalah,

$$
\begin{gathered}
V_{d c}=(1,2 \times 1,95)+(2 \times 0,0175 \times 1,2) \\
V_{d c}=2,4 \text { Volt }
\end{gathered}
$$

Namun pada proses perancangan dan percobaan, terjadi penurunan nilai tegangan. Sehingga arus yang disuplai tidak mencapai 1,2 ampere. Oleh karena itu, nilai tegangan suplai utama dari rangkaian demagnetisasi ini dinaikkan menjadi 3 Volt.

Alat demagnetisasi ini dipisah menjadi 2 bagian yaitu bagian pensaklaran dan bagian kontrol. Sehingga diperlukan 2 buah sumber tegangan DC sebagai suplai utama dan yang satu lagi sebagai input switching. Prinsip kerja dari alat demagnetisasi [1], [2] yaitu:

1. Sumber tegangan DC dimasukkan ke bagian 1 yaitu bagian switching yang berisikan 4 buah MOSFET, 2 buah halfbridge driver dan beberapa komponen pendukung seperti LED, resistor, dan kapasitor. Tegangan masukan utama sebesar 3 volt DC, sedangkan tegangan masukan untuk pin $\mathrm{Vb}$ pada gate driver sebesar 15 volt DC.

2. Bagian 2 yaitu kontroller yang berisikan sebuah modul buck converter, modul mikrokontroller arduino nano, dan beberapa komponen tambahan berupa resistor, kapasitor, LED, push button, serta layar LCD 16 × 2 juga diinjeksi dengan sumber tegangan DC untuk input vcc pada gate driver dan modul mikrokontroller. Besar tegangan input vec pada gate driver ini nilainya ditetapkan sebesar 12 volt DC. Namun sebelum menuju modul mikrokontroller, tegangan input 12 volt DC dari sumber tadi dikonversi menjadi 5 volt DC oleh modul buck converter.

3. Selanjutnya mikrokontroller diatur agar dapat menghasilkan pulsa PWM yang nantinya masuk ke dalam gate driver pada bagian pensaklaran untuk menyalakan MOSFET secara bergantian.

4. Saklar 1 dan saklar 2 menyala saat tegangan DC polaritas positif disalurkan ke transformator. Kemudian arus eksitasi DC akan naik secara linier dan kenaikan arus eksitasi hingga mencapai titik saturasi positif, seperti yang ditunjukkan oleh gambar 42, dibaca oleh sensor arus.

5. Ketika arus magnetisasi sudah mengalami kondisi saturasi yaitu pada titik a, maka sensor arus tadi akan memberikan sinyal kepada mikrokontroller sehingga saklar 1 dan saklar 
2 mati, berganti saklar 3 dan 4 yang menyala, sehingga polaritas tegangan suplai DC berganti ke polaritas negatif.

6. Arus magnetisasi kembali mengalami kondisi saturasi negatif pada titik c, sensor arus kembali memberikan sinyal kepada mikrokontroller agar kembali membalik polaritas tegangan suplai DC.

7. Dari titik c ke titik e inilah proses demagnetisasi berlangsung. Periode pensaklaran atau perubahan polaritas negatif menuju positif berlangsung dengan durasi setengah periode dari titik b ke c.

8. Durasi pensaklaran selanjutnya baik dari polaritas positif menuju ke negatif maupun dari polaritas negatif ke positif akan terus berkurang setengah dari gelombang sebelumnya.

Proses pensaklaran dimulai dengan frekuensi yang sangat rendah karena untuk mencapai kondisi saturasi diperlukan waktu yang cukup lama. Lamanya kondisi saturasi pada tiap transformator berbeda - beda karena hal itu berhubungan dengan tingkat kualitas inti besi transformator yang digunakan. Namun saat proses demagnetisasi berlangsung, frekuensi sumber tegangan tadi akan meningkat dan mengakibatkan proses pensaklaran menjadi semakin cepat. Oleh karena itu, alat demagnetisasi ini dinamakan alat demagnetisasi transformator satu fasa $1 \mathrm{kVA}$ dengan sumber tenaga berfrekuensi sangat rendah. Dari prinsip kerja alat demagnetisasi yang telah dijelaskan diatas, didapatkan persamaan periode pensaklaran berikut ini,

$$
\Delta t_{x}=\frac{\Delta t_{x-1}}{2}
$$

dimana:

$x=3,4,5, \ldots \ldots$

\section{Pengujian Alat Demagnetisasi dan Arus INRUSH}

\section{A. Pengujian Alat demagnetisasi}

Alat demagnetisasi yang telah dirancang dan telah dijelaskan pada bab 3, diuji di laboratorium untuk dianalisa apakah bisa menghasilkan gelombang kotak sinus seperti yang diharapkan. Seperti yang dibahas sebelumnya, alat demagnetisasi arus inrush pada transformator 1 fasa $1 \mathrm{kVA}$ ini berbasis metode Variable Frequency - Constant Voltage [1]. Hal itu menunjukkan bahwa aplikasi alat ini menggunakan sumber DC sebagai suplai utama yang diubah menjadi gelombang kotak AC dengan frekuensi yang bervariasi.

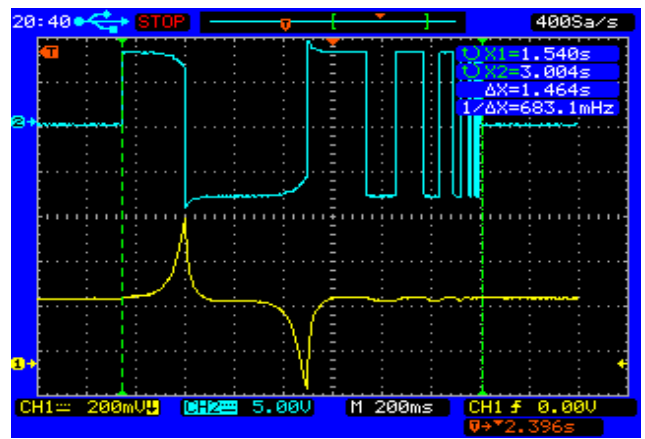

Gambar 5 Gelombang tegangan dan arus keluaran alat demagnetisasi
Dapat dilihat pada gambar 5 , proses demagnetisasi hanya membutuhkan waktu sekitar 1,5 detik saja atau lebih tepatnya 1,46 detik. Hal ini tentunya merupakan proses yang sangat cepat dan arus eksitasi DC yang masuk ke inti besi hamper mendekati 0 ampere di akhir proses tersebut.

Pada setengah gelombang dengan polaritas positif, seperti yang ditunjukkan oleh gambar 5, memiliki sinyal masukan sebesar 3 volt. Tetapi yang terbaca di osiloskop hanya 2,4 Vdc. Jika dianalisa, terjadi penurunan tegangan selama proses demagnetisasi berlangsung. Hal itu disebabkan oleh proses pensaklaran yang terjadi berulang kali dengan frekuensi yang semakin tinggi. Gambar 5 memperlihatkan perubahan tegangan dari polaritas negatif menjadi polaritas positif maupun sebaliknya pada saat frekuensi rendah hingga cukup tinggi. Sehingga untuk menghindari penurunan tegangan akibat proses pensaklaran, alat demagnetisasi diprogram agar berhenti beroperasi saat periode setengah gelombang sudah mencapai 0,1 mili detik.

Jika mengacu pada kedua gambar 5 tersebut, maka proses demagnetisasi sudah sesuai dengan yang telah dirancang sebelumnya. Kelemahan dari alat tersebut adalah tidak bisa mempertahankan nilai tegangan masukan, sehingga pada gelombang keluaran terdapat penurunan nilai akibat proses pensaklaran. Sesuai yang disebutkan pada referensi [2], sebenarnya proses demagnetisasi dianggap sudah selesai dengan periode satu setengah gelombang. Untuk mengatasi hal itu, pada modul mikrokontroller di program agar menghentikan proses pensaklaran saat setengah gelombang yang terakhir memiliki periode lebih dari sama dengan 10 mili detik. Dengan begitu diharapkan proses demagnetisasi dapat berjalan optimal dan dapat mengurangi fluks sisa pada inti transformator sehingga nilai arus inrush saat di energisasi dapat berkurang secara signifikan.

\section{B. Perbandingan Arus Inrush dan Analisa Data}

Proses pengujian dilakukan sebanyak 5 kali agar dapat dilakukan perbandingan durasi proses demagnetisasi dan besarnya arus inrush sebelum dan sesudah di demagnetisasi. Tahap - tahap pengujian dilakukan sesuai dengan diagram pada gambar 6 dan data diambil pada saat proses energisasi. Setelah mendapatkan ritme proses energisasi dan demagnetisasi, yaitu adanya interval waktu selama 10 menit, maka proses pengambilan data segera dilakukan. Kurva biru menunjukkan arus inrush sebelum demagnetisasi dan kurva merah menunjukkan arus inrush setelah demagnetisasi. 


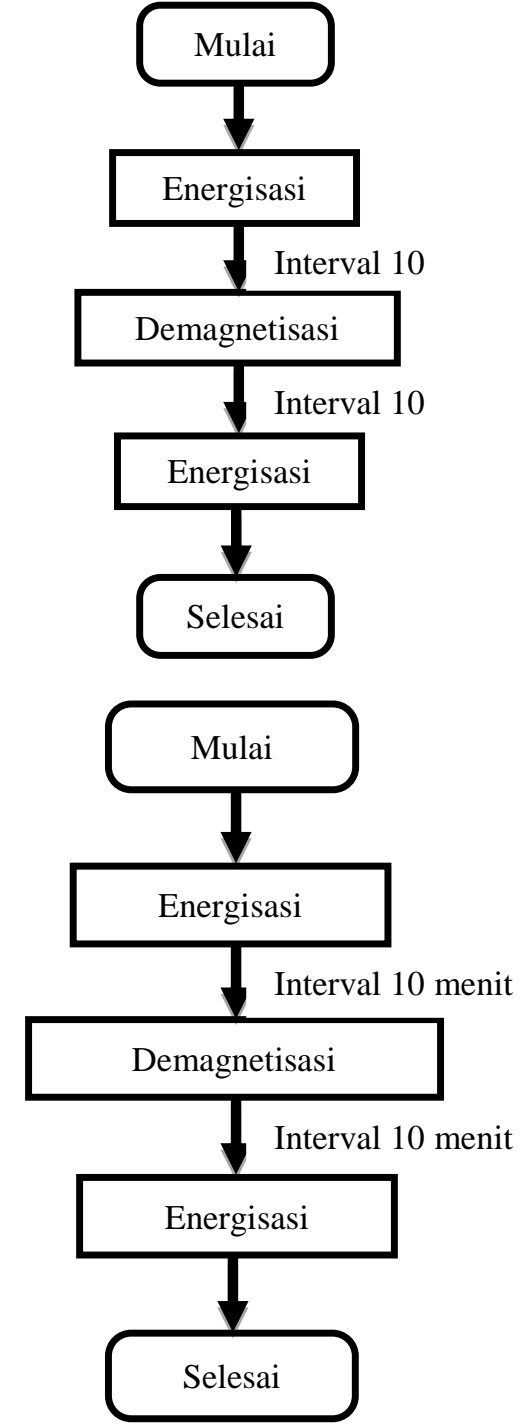

Gambar 6 Diagram proses pengujian arus inrush

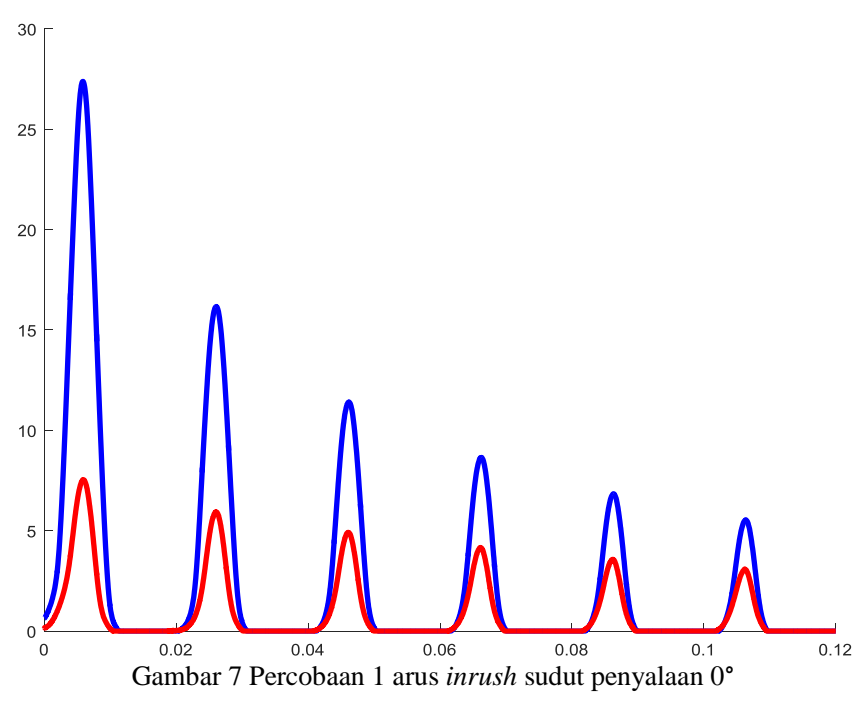

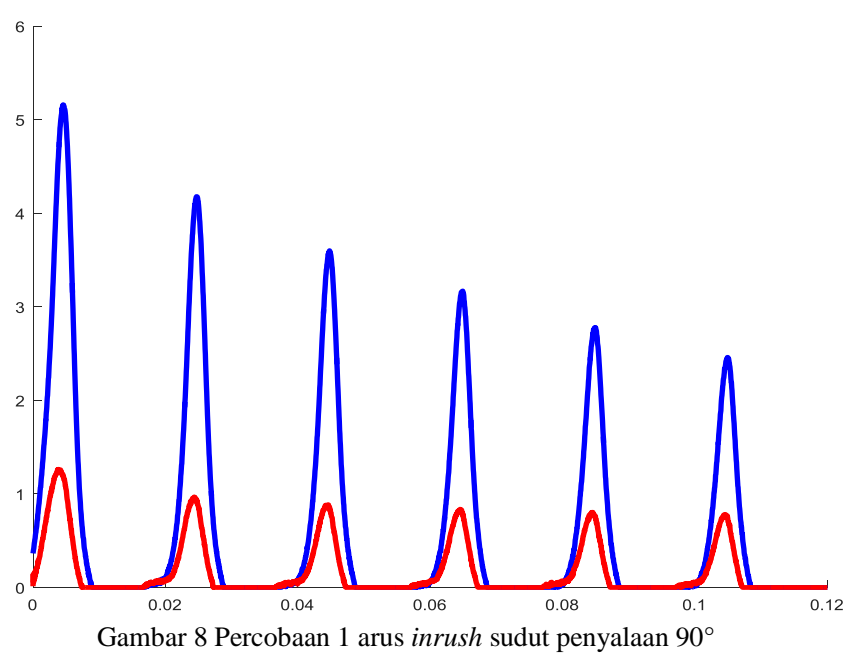

Setelah dilakukan pengujian energisasi dan demagnetisasi, dilakukan pengukuran menggunakan modul DAQ dan hasilnya ditampilkan dalam bentuk grafik pada layar monitor. Dari hasil pengujian dan pengukuran nilai arus inrush sebelum dan sesudah didemagnetisasi, didapatkan data sebagai berikut,

Tabel 1

Hasil pengukuran arus inrush sudut penyalaan $0^{\circ}$ dan $90^{\circ}$

\begin{tabular}{|c|c|c|c|c|c|}
\hline Sudut & $\begin{array}{l}\text { Arus } \\
\text { Inrush }\end{array}$ & Interval & Demagnetisasi & Interval & $\begin{array}{ll}\text { Arus } & \text { Turun } \\
\text { Inrush } & \end{array}$ \\
\hline
\end{tabular}

$\begin{array}{llllll}\left(^{\circ}\right) & (\mathrm{A}) & \text { (menit) } & \text { (detik) } & \text { (menit) } & \text { (A) }\end{array}$

\begin{tabular}{ccccccc}
\hline 0 & 27,4 & 10 & 1,46 & 10 & 7,6 & 72,3 \\
0 & 32 & 10 & 1,46 & 10 & 12,5 & 61 \\
90 & 5,2 & 10 & 1,46 & 10 & 1,26 & 75,8 \\
90 & 6,2 & 10 & 1,46 & 10 & 4 & 35,5 \\
\hline \hline
\end{tabular}

Data pada tabel 1 menunjukkan penurunan arus inrush pada saat dilakukan pengujian sebelum dan sesudah demagnetisasi. Data tersebut dapat dianalisa bahwa rata - rata proses demagnetisasi menghabiskan waktu sekitar 1,5 detik. Tentu saja hal itu merupakan proses yang cukup cepat mengingat pada alat demagnetisasi di program akan berhenti beroperasi saat periode setengah gelombang yang terakhir adalah 0,1 milidetik. Sedangkan untuk penurunan arus memiliki nilai yang berbeda - beda di setiap percobaan. Perbedaan ini disebabkan oleh jumlah fluks sisa yang terkumpul pada inti besi transformator. Semakin sering dienergisasi, maka fluks sisa juga semakin banyak. Akibatnya proses demagnetisasi menggunakan alat demagnetisasi arus inrush dengan sumber tenaga berfrekuensi sangat rendah hanya mampu mengurangi fluks sisa tidak sampai habis dari fluks sisa keseluruhan. Meskipun begitu, nilai maksimal dari arus inrush saat dienergisasi tetap berkurang.

Sebagai perbandingan, metode demagnetisasi Variable Frequency - Constant Voltage dibandingkan dengan metode demagnetisasi arus inrush yang lain yaitu menggunakan Variable Voltage - Constant Frequency (VVCF). Topik ini 
dikerjakan oleh salah satu rekan tugas akhir dan data yang didapatkan ditunjukkan oleh tabel berikut,

Tabel 2

Hasil demagnetisasi arus inrush menggunakan metode VVCF

\begin{tabular}{ccccccc}
\hline \hline Sudut & $\begin{array}{c}\text { Arus } \\
\text { Inrush } \\
\left({ }^{\circ}\right)\end{array}$ & $\begin{array}{c}\text { Interval } \\
(\text { (menit })\end{array}$ & Demagnetisasi & Interval & $\begin{array}{c}\text { Arus } \\
\text { Inrush }\end{array}$ & Turun \\
\hline 0 & 30,78 & 10 & 2 & 10 & 25,05 & 18,6 \\
90 & 8,22 & 10 & 2 & 10 & 5,5 & 33,1 \\
\hline \hline
\end{tabular}

Data yang didapatkan pada tabel 2 dibandingkan dengan data pada tabel 1 , jika dianalisa terdapat perbedaan yang sangat signifikan mengenai waktu yang dibutuhkan dalam proses demagnetisasi. Metode VFCV dapat melakukan proses demagnetisasi lebih cepat daripada metode VVCF [1]. Hal ini terjadi karena perbedaan metode yang digunakan saat merancang alat dimana metode VFCV yang dibahas pada tugas akhir kali ini dirancang sedemikian rupa agar berhenti bekerja saat setengah gelombang terakhir dari tegangan keluaran memiliki periode 0,1 milidetik. Sedangkan untuk metode VVCF dirancang agar berhenti bekerja saat sudah mencapai satu setengah gelombang saja. Seharusnya alat demagnetisasi berbasis metode VFCV bekerja lebih lama tetapi tetap saja hasil pengujian menunjukkan bahwa alat demagnetisasi yang menggunakan metode VFCV membutuhkan waktu yang singkat. Namun untuk hasil demagnetisasi yang ditunjukkan oleh persentase penurunan pada kolom paling kanan di tabel 2 tidak terlalu signifikan jika dibandingkan dengan metode VFCV. Sehingga dapat disimpulkan bahwa alat demagnetisasi arus inrush dengan sumber tenaga berfrekuensi sangat rendah berbasis metode Variable Frequency - Constant Voltage memerlukan waktu sedikit lebih cepat dalam melakukan proses demagnetisasi, tetapi hasil yang didapatkan sangat optimal.

\section{KESIMPULAN}

Besarnya nilai arus inrush saat pertama kali dienergisasi dengan sumber tegangan bolak - balik bergantung pada sudut fasa tegangan tersebut dan besarnya fluks sisa yang terdapat pada inti besi transformator. Alat Demagnetisasi Arus Inrush dengan Sumber Tenaga Berfrekuensi Sangat Rendah berbasis metode Variable Frequency - Constant Voltage terbukti berhasil melakukan proses pengurangan fluks sisa pada inti transformator satu fasa $1 \mathrm{kVA}$ sehingga nilai dari arus inrush setelah didemagnetisasi bisa lebih rendah dari nilai arus inrush sebelum proses demagnetisasi dilakukan. Hasil yang didapatkan ketika menggunakan alat demagnetisasi berbasis metode Variable Frequency - Constatn Voltage bisa lebih optimal daripada alat demagnetisasi yang menggunakan metode Variable Voltage - Constant Frequency. Hal ini dibuktikan dengan perbedaaan penurunan persentase arus inrush pada metode VFCV yang mencapai lebih dari 50\% dan metode VVCF yang maksimal hanya mencapai $37,3 \%$. Perbandingan ini tentunya dilakukan dengan parameter transformator yang sama, serta interval antara proses energisasi dan demagnetisasi yang sama.

\section{DAFTAR PUSTAKA}

[1] K. Baris, L. d. Francisco, C. Dariusz, Z. Zivan, and B. Leo, “Mitigation of Inrush Currents in Network Transformers by Reducing the Residual Flux with an Ultra-Low-Frequency Power Source", IEEE Trans. Power Del., vol. 26, no. 3, pp. 1563 - 1570, July. 2011.

[2] F. de Leon, Ashkan Farazmand, Saeed Jazebi, Digvijay Deswal, dan Raka Levi, "Residual Flux in Transformer by Application of an Alternating Polarity DC Voltage Source", IEEE Transactions on Power Delivery, Vol. 30, no. 4, August 2015.

[3] H. Brunke and K. J. Frohlich, "Elimination of Transformer Inrush Currents by Controlled Switching. I. Theoretical Considerations", IEEE Trans. Power Del., vol. 16, no. 2, pp. 276-280, April. 2001.

[4] H. Brunke and K. J. Frohlich, "Elimination of Transformer Inrush Currents by Controlled switching. II. Application and Performance Considerations", IEEE Trans. Power Del., vol. 16, no. 2, pp. 281-285, April. 2001.

[5] F. de León, A. Farazmand, and P. Joseph, "Comparing the T and Pi Equivalent Circuits for the Calculation of Transformer Inrush Currents", IEEE Trans. Power Del., vol. 27, no. 4, pp. 2390-2398, October. 2012.

[6] M. Jamali, M. Mirzaie, and S. Asghar Gholamian, "Calculation and Analysis of Transformer Inrush Current Based on Parameters of Transformer and Operating Conditions", ISSN 1392-1215 @2011

[7] Firmansyah Mokhamad, IGN Satriyadi, Soedibjo, "Studi Perbandingan Metode Pengurangan Arus Inrush pada Transformator Daya 500 kV GITET Krian", Jurnal Teknik Pomits, vol. 1, no. 1, pp. 1 -6, 2014. 